\title{
Variations of Celiac Artery in Dogs: Anatomic Study for Experimental, Surgical and Radiological Practice
}

\author{
Variaciones de la Arteria Celiaca en Perros: Estudio Anatómico \\ para Prácticas Experimental, Quirúrgica y Radiológica
}

\section{"M. Abidu-Figueiredo; "G. P. Dias; "S. Cerutti; "B. Carvalho-De-Souza; "R. S. Maia \& **M. A. Babinski.}

\begin{abstract}
ABIDU-FIGUEIREDO, M.; DIAS, G. P.; CERUTTI, S.; CARVALHO-DE-SOUZA, B.; MAIA, R. S. \& BABINSKI, M. A. Variations of celiac artery in dogs: Anatomic study for experimental, surgical and radiological practice. Int. J. Morphol., 23(1):37-42, 2005.
\end{abstract}

SUMMARY: The purpose of this study is gain a better understanding of the anatomical variations of celiac artery and its branches in dogs.

The celiac artery supply was analyzed in thirty dogs. The animals were injected with solution of Petrolatex S65 and dissected to evidence the celiac artery origin and its proximal ramifications. The celiac artery and its proximal branches were dissected and lengthen.

The celiac artery more frequently emerged ahead of the first lumbar vertebra in one way form. The medium length of the celiac artery was of $0.98 \mathrm{~cm}$. The gastrolienal trunk was the predominant morphological arrangement with medium length of $0.19 \mathrm{~cm}$. The lienal artery emerged in one way form emitting more frequently 2 main branches. A branch emerging of the celiac artery irrigating the left adrenal occurred in 4 animals. The left gastric artery presented 1 branch in 17 animals (56.7\%), 2 branches in 11 animals (36.6\%) and 3 branches in 3 animals (10\%). The left pancreatic lobe received a main branch from the lienal artery in 24 animals ( $80.0 \%)$, two branches in 4 animals (13.4\%), and a branch emerging of the gastrolienal trunk in 2 animals (6.6\%).

The present data should therefore provide important information for devising experiments and interpreting results when using the mongred dogs as a model for experimental surgery and radiolocal practice of the celiac artery specially when making comparisons to human anatomy.

KEY WORDS: Dog; Celiac artery; Anatomy.

\section{INTRODUCTION}

A knowledge of the variations of celiac artery has importance in a program of systematization of radiological and surgical anatomy in the most common experimental animals, abdominal arteries have been considered by means of either dissective or angiographic study. Particular attention has been paid to the study of visceral arteries and renal pedicles, outlining the differences noticed among various animal species (Farinon et al., 1984).

Several authors (Kennedy \& Smith, 1930; Sleight \& Thomford, 1970; Enge \& Flatmark, 1972; Borelli \& Boccalletti, 1974; Schmidt et al., 1980; Bednarova \& Malinovsky, 1984; Niza et al., 2003) have studied the ramification of the celiac artery in vertebrates. They showed that the organization of the celiac artery and its branches present several variations and the study of this variability is of practical, as well theoretical, significance in both experimental and domestic animals (Bednarova \& Malinovsky).

The celiac artery emerges of the ventral surface of the abdominal aorta as its first visceral branch. It is approximately $4 \mathrm{~mm}$ in diameter and $2 \mathrm{~cm}$ long. The celiac trunk anatomical relations are on the left with the stomach and on the right with the liver and the adrenal gland. The left lobe of the pancreas bounds it caudally. The celiac artery is divided in three branches: the hepatic artery, the lienal artery and the left gastric artery. The celiac artery usually trifurcates, although in some specimens the left gastric and lienal arteries emerge of a short common trunk (Nickel et al., 1979; Evans \& Lahunta, 1993; Dyce et al., 1997). Kennedy \& Smith

\footnotetext{
* Department of Animal Anatomy - Federal Rural University of Rio de Janeiro, UFRRJ (RJ), Brazil.

**Department of Morphology - Fluminense Federal University, UFF (RJ), Brazil.
} 
recorded a case in which the lienal artery emerged from the cranial mesenteric. Small and inconstant pancreatic and phrenic branches may emerge from the celiac artery. In spite of proximal branches and celiac artery anatomy, good studies were performed in the past (Kennedy \& Smith; Pott, 1949; Enge \& Flatmark; Schmidt et al.; Niza et al.).

Recent advances and refinements in radiological interventional procedures as well as in experimental model for vascular surgery have revived interest in vascular anatomy, since a thorough understanding of such anatomy is mandatory to perform such procedures safely and efficiently. We belive that nowadays, a timely and objective source, incorporating up-to-date practical application concerning celiac artery anatomy is important for interventional radiologists and veterinary surgeons, as well as focuses on the experimental model for vascular surgery (Farinon et al.) when made with dogs. Therefore, the purpose of this study is gain a bettter understanding of the anatomical variations of celiac artery and its branches in dogs.

\section{MATERIAL AND METHOD}

The local ethics committee on animal research approved this study. The anatomical dissections were performed in 30 adult dogs: 11 males and 19 females. They weighed between 10 and $20 \mathrm{Kg}$ and their rostrum-sacral length was around $75.18 \mathrm{~cm}$. The animals were obtained from the Necropsy Unit of the Rural Federal University of Rio de Janeiro and had been dissected between 2002 and 2004. The abdomen was opened by an incision on the white line following by other behind the last rib to expose the abdominal organs. The abdominal aorta artery was dissected immediately below the diaphragm until the emergency of the renal arteries. The abdominal aorta artery was cannulated with a stem of plastic measuring $0.4 \mathrm{~cm}$ of diameter. The vascular system was washed with saline solution and then filled with coloured Petrolatex S 65. The celiac trunk and its proximal branches were "in situ" dissected and lengthen. The veterinary anatomic nomenclature (Shaller, 1999) and guide to the dissection of the dog (Evans \& Lahunta,1993) were used.

Statistical Analysis:To verify if the distribution of frequencies observed for the 30 examined animals is in accordance with the literature, we applied a tack test proceeded by the $\mathrm{X}^{2}$ test (qui-square) with a level of significance of $5 \%$ to test if the nullity hypothesis is true for the number of gastric arteries, the origin of the celiac artery and the number of main ramifications of the lienal artery. The relation between the length of the celiac artery and the rostrum-sacral length was calculated by the coefficient of correlation " $r$ " varying between -1 and +1 , that is, $-1 \leq \mathrm{r} \leq+1$.

\section{RESULTS}

The celiac artery emerged of the abdominal aorta artery in one way form in all the examined animals. The medium length of the celiac artery was of $0.98 \mathrm{~cm}$. The celiac artery originated at the level of the first lumbar vertebra in 22 animals $(73.4 \%)$, between the first and second lumbar vertebrae in 6 animals $(20 \%)$ and at the level of the second lumbar vertebra in 2 animals $(6.6 \%)$. No relation was observed between the length of the celiac artery and the rostro-sacral length. The occurrence of the typical three-branched celiac artery (Fig. 1a; for a schematic drawing, see Fig.1b) was observed in 10 animals (33.3\%). The emergence of the gastrolienal trunk (Fig.2a; for a schematic drawing, see Fig.2b) bifurcating with the hepatic artery occurred in 17 animals (56.7\%). The medium length of the gastrolienal trunk was of $0.19 \mathrm{~cm}$. It was observed a variation that consisted of the existence of two left gastric arteries associated with the hepatic and lienal arteries in 3 animals (10\%). In relation to the celiac artery, the common hepatic artery emerged cranially in 23 animals $(76.7 \%)$ and right lateral in 7 animals $(23.3 \%)$, in both cases its emergency was in one way form. In all the animals the common hepatic artery presented cranioventral passage.

The left gastric artery presented three distinct forms: one way form in 16 animals $(53.4 \%)$, pair in 11 animals $(36.6 \%)$ and triple in 3 animals (10\%). In all the dissected animals the lienal artery emerged directly of one way form of the celiac trunk or the gastrolienal trunk, after that it was divided in two branches in 28 animals (93.3\%) and in three branches in 2 animals $(6.7 \%)$. The numbers of gastric arteries, main ramifications of the lienal artery, as well as the origin of the celiac artery are independent of the sex of the animal. Directly of the celiac artery emerged a branch for the left adrenal gland in 4 animals (13.3\%) and in 26 animals $(86.7 \%)$ this branch was not found. The left pancreatic lobe received a main branch from the lienal artery in 24 animals $(80.0 \%)$, two branches in 4 animals (13.4\%), and a branch emerging of the gastrolienal trunk in 2 animals $(6.6 \%)$. It had predominance of the gastrolienal trunk in the dissected animals.

All the analyzed statistical parameters are independent of sex or race, as well as length. 

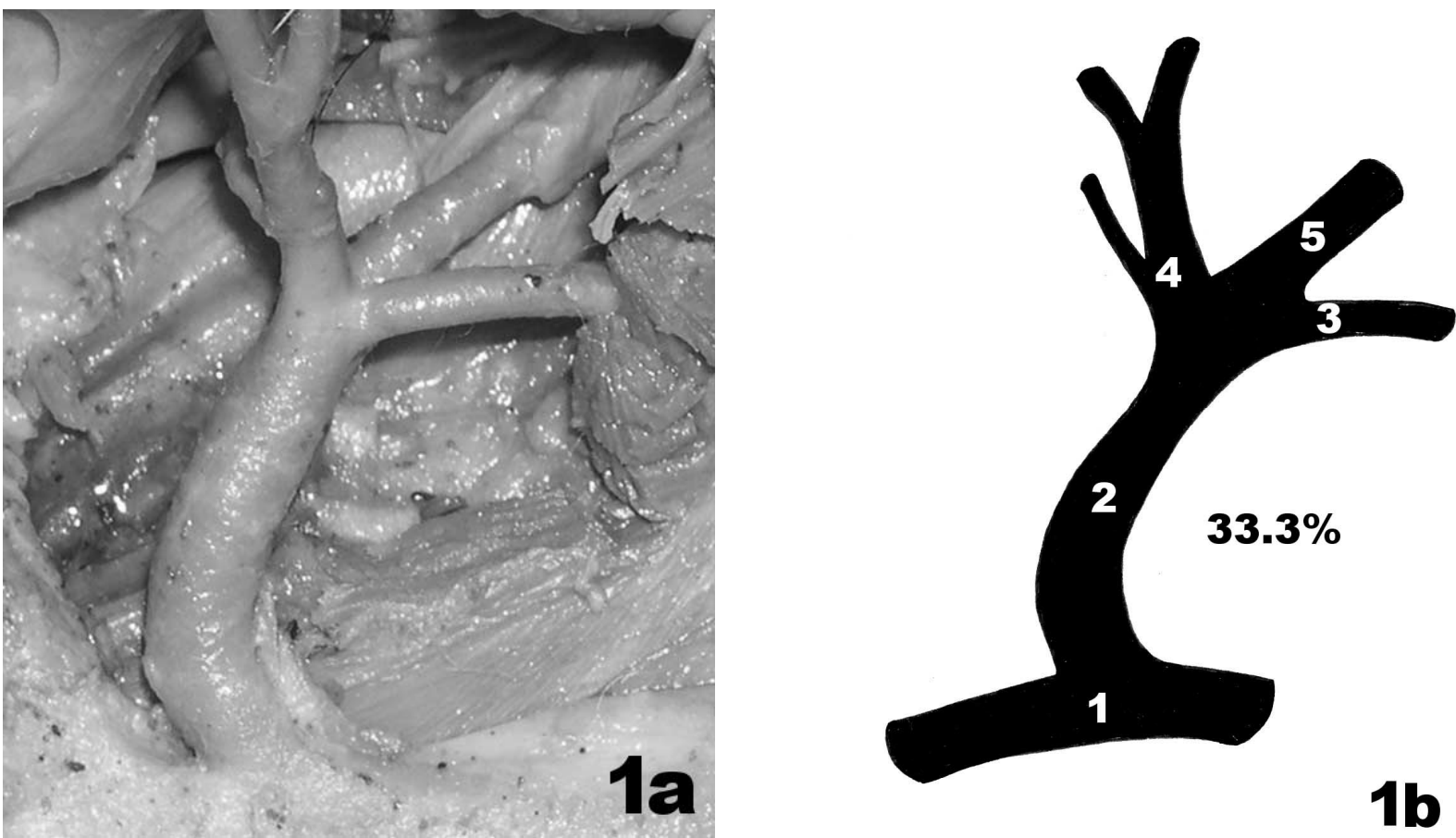

Fig.1a. Photomacrography of the celiac artery dissected from 30 dogs injected with latex; Fig. 1b. Lateral views of anatomic drawings display the aortic artery and the occurrence of the typical three-branched celiac trunk was observed in 10 animals (33.3\%). 1. Aortic artery; 2. Celiac artery; 3. Hepatic artery; 4. Lienal artery; 5. Left gastric artery.
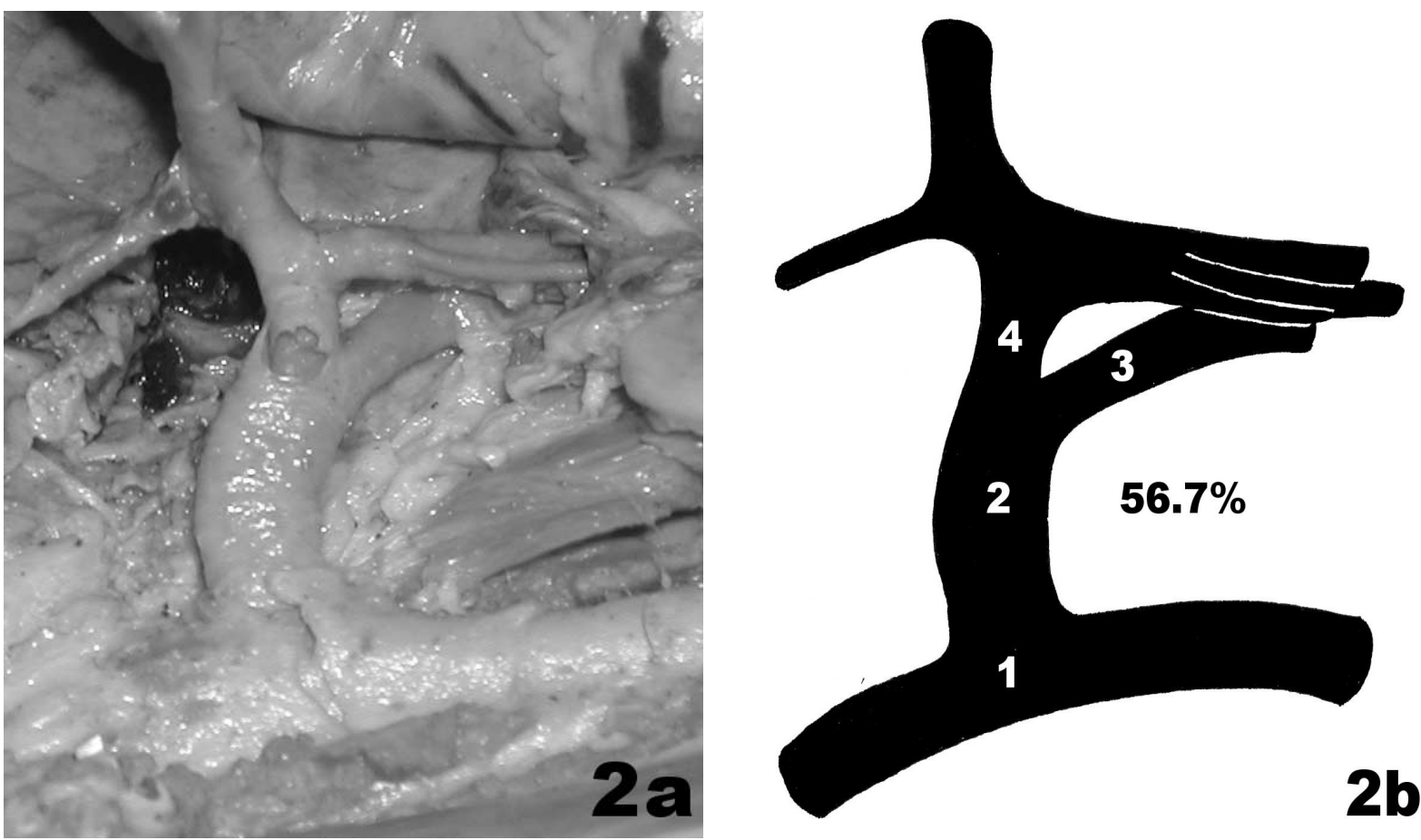

Fig. 2a. Photomacrography of the celiac artery dissected from 30 dogs injected with latex; Fig. 2b. Lateral views of anatomic drawings display the aortic artery (1) and the percentual emergence (56.7\%) of the celiac artery (2) bifurcating with the hepatic artery (3) and gastrolienal trunk (4). 


\section{DISCUSSION}

Although several authors have consistently described the celiac artery and its branches, this vessel presents several variations which may occur at all levels (Niza et al.). The celiac artery emerged in one way form in all the examined animals. These results have been consistent with the ones that were obtained by Pott, Borelli \& Boccalletti who performed dissections on 37 and 50 cats, respectively. Berg (1961) however, dissected 100 cats and found variations in two cats. In the first one, the celiac artery emerged together with the mesenteric-cranial artery and in the other one he noticed the presence of a celiac-mesenteric trunk. Bednarova $\&$ Malinovsky dissected 30 cats and found the celiac artery emerging in one way form. They have not found the celiacmesenteric trunk in any of the animals.

The celiac artery in carnivorous animals is usually originated at the level of the first lumbar vertebra (Schwarze, 1970; Nickel et al.), but it may also be originated between the 13th abdominal vertebra and the 1st lumbar vertebra (Niza et al.). In the animals dissected in this study, we found out that this origin may occur more frequently $(76.7 \%)$ in the first lumbar vertebra and in the second lumbar vertebra $(23.3 \%)$ or between the first and the second lumbar vertebrae.

Through the selective angiography, Enge \& Flatmark confirmed the classical descriptions, noticing that in most of the examined canidae, the celiac artery is divided in three branches: the hepatic artery, the spleenic artery and the left gastric artery. This result is not consistent with the ones obtained in this research in which the classical trifurcation was found in $33.3 \%$ and the gastrolienal trunk was found in $56.7 \%$ of the examined animals. A little frequent variation was also found and it showed two left gastric arteries associated with the hepatic and lienal arteries in $10 \%$ of the animals, while Sleight \& Thomford, with the utilization of the necropsy dissection method noticed this same variation in only $2 \%$ of the cases, the trifurcation in $64 \%$ of the cases and the bifurcation in $34 \%$. The existence of two left gastric arteries emerging of the lienal artery was also reported by Schmidt et al. These authors, through angiography, corrosion and dissection models, noticed that most of the celiac arteries end in two branches: the hepatic artery and the gastrolienal trunk. This one divides itself subsequently to originate the left gastric artery and the lienal artery. This ending in two branches was found in $66 \%$ of the cases whereas the classical trifurcation was found in only $34 \%$. Schmidt et al. also described a less frequent anomaly in which the lienal artery originated in the cranial mesenteric artery instead of in the celiac artery, as it usually happens.
According to what has already been mentioned, in our dissected animals the most frequent feature was the presence of the gastrolienal trunk. Niza et al. through angiographic studies and dissection comment on the existence of an emerging gastrolienal trunk. It was the most frequent situation found in their works (65\%). In the animals which did not present a gastrolienal trunk, the left gastric artery emerged directly from the celiac artery. This condition was also described by Enge \& Flatmark; Schmidt et al.

Getty (1981), in relation to the artery supply of the adrenal gland, says that it may come from the branches of the renal arteries, straight from the aorta, from the frenic abdominal artery and, occasionally, from the lumbar arteries. In this study, we have noticed the presence of a branch of the celiac artery irrigating the left adrenal gland in four animals (13.3\%).

Bednarova \& Malinovsky (1984) identified, in dissections performed on 34 cats, the most frequent morphological arrangement, which is the classical trifurcation, refuting the results obtained by Berg, Borelli \& Boccalletti, in which the presence of the gastrolienal trunk was the predominant formation. The left gastric artery may originate straight from the celiac artery or through a common trunk with the lienal artery, bifurcating itself with the common hepatic artery (Schwarze; Nickel et al.; Niza et al.). In the results described in this study, the left gastric artery appears in a one, a double or a triple aspect. Bednarova \& Malinovsky, while studying the celiac artery and its ramifications in a cat, commented that the left gastric artery had a separate origin in $60 \%$ of the dissected animals, and that in $40 \%$ of them this origin occurred associated with the gastrolienal trunk.

In humans, the celiac artery emerges ahead of the 12th thoracic vertebra and may be shorter or longer than usual (Bergman et al., 1988; Williams et al., 1989; ). If compared to our data, the origins in the canidae emerge after the first lumbar vertebra. The length of the celiac artery found in our study $(0.98 \mathrm{~cm})$ is similar to the men's $(0.8$ to $1.5 \mathrm{~cm})$. A typical three-branched celiac artery occurred in $86 \%$ of the 756 cases studied (Bergman et al.). Our results, however, show a lower percentage of this occurrence: $33.3 \%$, that is, in 10 out of 30 dogs. Variations in humans are many (Testut \& Jacob, 1926; Bergman et al.; Williams et al.), and the main ones are: a fourth branch, in approximately $10 \%$, the pancreatic-duodenal branch (Putz \& Pabst, 2000), at the same percentage as seen in our study (10\%). However, the quadrifurcation consisted of the existence of two left gastric 
arteries associated with the hepatic and the lienal arteries in $5 \%$ to $7 \%$ of the cases studied, the presence of the hepatolienal trunk; the gastrolienal trunk may appear in $3 \%$ whereas in our study it appeared in 56.7\% (17 animals) and it also showed up together with the hepatic-mesenteric trunk (Bergman et al.; Putz \& Pabst).

No relation was observed between the length of the celiac artery and the rostro-sacral length. The numbers of gastric arteries, main ramifications of the lienal artery, as well as the origin of the celiac artery are independent of the sex of the animal. It had predominance of the gastrolienal trunk in the dissected animals. In addition, the present data should therefore provide important information for devising experiments and interpreting results when using the mongred dogs as a model for experimental, surgical and radiological practice of the celiac artery, specially when making comparisons to human anatomy.

Acknowledgments: The authors thank Mr. Rafael L.R. Maciel for performing the schematical drawings and Ms. Themis M Cardinot for the English translation.

M. ABIDU-FIGUEIREDO; G. P. DIAS; S. CERUTTI; B. CARVALHO-DE-SOUZA; R. S. MAIA \& M. A. BABINSKI. Variaciones de la arteria celiaca en perros: Estudio anatómico para prácticas experimental, quirúrgica y radiológica. Int. J. Morphol., 23(1):37-42, 2005.

RESUMEN: El propósito de este estudio es comprender mejor las variaciones anatómicas de la arteria celiaca y de sus ramas en los perros.

Estudiamos la arteria celiaca en 30 perros (Canis familiaris). La parte abdominal de la aorta y el tronco celiaco fueron inyectados con una solución de Petrolatex S65, disecándose, desde su origen, la arteria celiaca y sus ramificaciones proximales.

La arteria celiaca se originaba, de manera más frecuente, a nivel de la primera vértebra lumbar. La longitud media de la arteria celiaca fue de $0.98 \mathrm{~cm}$. El tronco gastrolienal era el elemento morfológico predominante, con una longitud promedio de $0.19 \mathrm{~cm}$. La arteria lienal se originaba de un tronco y emitía, frecuentemente, dos ramas principales. En 4 animales, se originaba una rama de la arteria celiaca, la cual irrigaba la glándula adrenal izquierda. La arteria gástrica izquierda emitía una rama en 17 animales (56.7\%), dos ramas en 11 animales (36.6\%) y 3 ramas en 3 animales (10\%). El lóbulo pancreático izquierdo recibía una rama principal de la arteria lienal en 24 animales (80.0\%), 2 ramas en 4 animales (13.4\%), y una rama que se originaba del tronco gastrolienal en 2 animales (6.6\%).

Los resultados obtenidos se deben tener presentes cuando son utilizados perros como modelo en cirugía experimental y práctica radiolocal, especialmente, cuando se hacen comparaciones con la anatomía humana.

PALABRAS CLAVE: Perro; arteria celiaca; Anatomía.

\section{REFERENCES}

Bednarova, Z. \& Malinovsky, 1. Ramification of celiac artery in the domestic cat. Folia Morphol., 34 (1):36-44, 1984.

Berg, R. Systematische Untersunchungen Uber das Verhalten der Aste der Aorta Abdominalis Bei Felis Domestica. Anat. Anz., 110:239-50, 1961.

Bergman, R. A.; Thompson, S. A.; Afifi, A. K. \& Saadeh, F. A. Compendium of human anatomic variation: Catalog, Atlas and World Literature. Munich, Urban \& Schwarzenberg, 1988.

Borelli, V. \& Boccalletti, D. Ramificação das artérias celíaca e mesentérica cranial no gato (Felis Catus Domestica). Rev. Fac. Med. Vet. Zootec. Universidade de São Paulo, 11:263-70, 1974
Dyce, K. M.; Sack, W. O. \& Wensing, C. G. Tratado de Anatomia Veterinária. 2. ed. Rio de Janeiro, Guanabara Koogan, 1997.

Enge, I. \& Flatmark, A. Selective coeliac and hepatic artery angiography in normal dogs. Scan. J. of Gastroent., 7:361-8. 1972.

Evans, H.E. \& Lahunta. D. E. Guide to the dissection of the dog. 5. ed. Philadelphia, W. B. Saunders Company, 1993.

Farinon, A.M.; Lampugnani, R.; Zannoni, M.; Delfrate, R.; Freddi, R. In tema de Anatomia Chirurgica dei Vasi Arteriosi Addominali Nei Piu Comuni Animali da Esperimento. Chir. \& Pat. Sper., 32 (1):17-27, 1984.

Getty R. Anatomia dos animais domésticos. 5. ed. Rio de Janeiro, Guanabara Koogan, 1981. 
Kennedy, H.N. \& Smith, A.W. An abnormal celiac artery in the dog. Vet. Record., 10:751, 1930.

Nickel, R.; Schummer, A. \& Seiferle, E. The viscera of domestic mammals. 2. ed. Berlin, Verlag Paul Parey, 1979.

Niza, M. M. R. E.; Vilela, C. L.; Ferreira, A. J. A.; Gonçalves M.S. \& Pisco, J.M. Irrigação arterial hepática em canídeo. Ver. Port. Ciênc. Vet., 98(546):69-6, 2003.

Pott, G. Die Arterielle Blutversorgung des Magen-DarmKanais, Seiner Anhangsdrusen (leber,pancreas) Und Der Milz Bei Der Katze. Vet. Med. Diss. Hannover, 1-20, 1949.

Putz, R. \& Pabst, R. Sobotta: Atlas de Anatomia Humana. 21. ed. Rio de Janeiro, Guanabara Koogan, 2000.

Schmidt, S.; Lohse, C. L. \& Suter, P. F. Branching Pat-Terns of the hepatic artery in the dog: Arteriographic and anatomic study. Am. J. Vet. Res. 41:1090-7, 1980.

Schaller, O. Nomenclatura Anatômica Veterinária Ilustrada. 1. ed. São Paulo, Manole, 1999.

Schwarze, E. Compendio de Anatomia Veterinária. 3. ed. Zaragoza, Acribia, 1970.

Sleight, D. R. \& Thomford, N. R. Gross anatomy of the blood supply and biliary drainage of the canine liver. Anat. Record., 166:153-60, 1970.

Testut, L. \& Jacob,O. Anatomía Topográfica. Barcelona, Salvat, 1926. Tomo I.

Williams, P. L.; Warwick, R.; Dyson, M.; Bannister, L. H. Gray's Anatomy. 37. ed. New York, Churchill Livingstone, 1989.
Correspondence to:

Prof. Dr. Marcelo Abidú Figueiredo

Instituto de Biologia - Departamento de Anatomia Animal

Universidade Federal Rural do Rio de Janeiro - UIFR

Rodovia BR 465, Km7, s/n

CEP 23890-000

Seropédica

Rio de Janeiro - BRASIL

E-mail:abiduanat@ufrrj.6r

abidu_ma@yahoo.com

Received: 10-12-2004

Accepted: 17-01-2005 